\title{
THE CONCENTRATION OF SODIUM, POTASSIUM, CALCIUM, INORGANIC PHOSPHATE, PROTEIN AND GLYCERYLPHOSPHORYLCHOLINE IN THE EPIDIDYMAL PLASMA OF BULL CALVES
}

\author{
B. GRABO, B. GUSTAFSSON, A. BANE, P. MESCHAKS \\ AND J. E. RINGMAR \\ Departments of Clinical Biochemistry and of Obstetrics and Gynaecology, \\ Royal Veterinary College, Stockholm, Sweden
}

(Received 30th December 1966)

During their passage along the epididymal duct the spermatozoa undergo several changes (cf. Bishop, 1961) which may be related to changes in the composition of the epididymal plasma. It is known that in adult bulls the epididymal plasma changes characteristically in composition from one segment of the epididymal duct to another (Crabo \& Gustafsson, 1964; Crabo, 1965).

TABLE 1

DATA GONGERNING THE TESTES AND EPIDIDYMIDES OF GALVES STUDIED

\begin{tabular}{l|c|c|c|c|c|c}
\hline & $\begin{array}{c}\text { Age } \\
(\text { days })\end{array}$ & $\begin{array}{c}\text { Body weight } \\
(\mathrm{kg})\end{array}$ & $\begin{array}{c}\text { Weight of } \\
\text { the testes } \\
(\mathrm{g})\end{array}$ & $\begin{array}{c}\text { Tubules with } \\
\text { primary sper- } \\
\text { miocytes }(\%)\end{array}$ & $\begin{array}{c}\text { Diameter of } \\
\text { tubules } \\
(\mu)\end{array}$ & $\begin{array}{c}\text { Weight of } \\
\text { epididymides } \\
(\mathrm{g})\end{array}$ \\
\hline Mean & $226 \cdot 9$ & $196 \cdot 6$ & $152 \cdot 4$ & $63 \cdot 6$ & $149 \cdot 9$ & $19 \cdot 8$ \\
SD & $10 \cdot 4$ & 30.6 & $54 \cdot 1$ & $39 \cdot 9$ & $23 \cdot 4$ & 7.5 \\
Range & $209-242$ & $152-252$ & $79-268$ & $0-100$ & $124-186$ & $12-39$ \\
\hline
\end{tabular}

Note: (1) The total number of animals studied, was eighteen; and (2) spermatozoa were present in the testes of nine animals, and in the cauda epididymidis of two animals.

Employing the method previously developed by Crabo (1965), it was decided to perform analyses of the epididymal plasma of bull calves before or at the time when spermatozoa appear in the epididymal duct, and to compare the composition of the epididymal plasma in bull calves with that in adult bulls.

The material consisted of eighteen bull calves aged from 209 to 242 days, of Swedish Red and White breed, and crosses between this breed and the Swedish Friesian breed, Aberdeen Angus, Hereford and Charolais (Table 1). Testicles and epididymides were removed under local anaesthesia with Xylocaine . For chemical examination, the material was collected: (i) at the junction between the rete testis and the efferent ducts, and (ii) from the cauda epididymidis. To obtain a sufficient quantity, the material from the epididymides of both sides was pooled. The amounts obtained from segments of the epididymal duct other than the cauda were insufficient for analysis by this 
method. The chemical methods were the same as employed earlier by Crabo (1965). Standard statistical methods were used for all calculations (cf. Snedecor, 1946).

The results of the chemical examination are shown in Table 2, which gives also a statistical comparison between the fluids from the rete testis and cauda

TABLE 2

THE CONCENTRATION OF SODIUM, POTASSIUM, GALGIUM, INORGANIC PHOSPHATE, PROTEIN AND GLYGERYLPHOSPHORYLCHOLINE (GPC) IN THE FLUIDS TAKEN FROM THE RETE TESTIS AND CAUDA EPIDIDYMIDIS OF CALVES

\begin{tabular}{|c|c|c|c|c|c|c|}
\hline & $\begin{array}{c}\mathrm{Na}^{+} \\
(m-\text { equiv } / l)\end{array}$ & $\underset{(m-e q u i v / l)}{K^{+}}$ & $\underset{(m-e q u i v / l)}{C a^{++}}$ & $\underset{(m \text {-moles } / l)}{\mathrm{PO}_{4}}$ & $\begin{array}{c}\text { Protein } \\
(m g \mathcal{N} / m l)\end{array}$ & $\begin{array}{c}G P C \\
(m-m o l e s / l)\end{array}$ \\
\hline $\begin{array}{l}\text { Rete testis } \\
\text { No. of animals }\end{array}$ & 11 & 11 & 6 & 7 & 7 & 8 \\
\hline Mean content & $\begin{array}{c}139 \cdot 1 \\
(130 \cdot 0)\end{array}$ & $\begin{array}{c}8 \cdot 3 \\
(14 \cdot 7)\end{array}$ & $\begin{array}{c}3 \cdot 36 \\
(2 \cdot 26)\end{array}$ & $\begin{array}{c}1 \cdot 10 \\
(6 \cdot 52)\end{array}$ & $\begin{array}{c}4 \cdot 5 \\
(2 \cdot 2)\end{array}$ & $\begin{array}{c}2 \cdot 7 \\
(4 \cdot 3)\end{array}$ \\
\hline $\mathrm{SD}$ & $\begin{array}{l}14 \cdot 3 \\
(8 \cdot 5)\end{array}$ & $\begin{array}{c}2 \cdot 6 \\
(4 \cdot 4)\end{array}$ & $\begin{array}{c}1.95 \\
(0 \cdot 68)\end{array}$ & $\begin{array}{c}2 \cdot 91 \\
(6 \cdot 54)\end{array}$ & $\begin{array}{c}3 \cdot 3 \\
(2 \cdot 1)\end{array}$ & $\begin{array}{c}3 \cdot 0 \\
(4 \cdot 3)\end{array}$ \\
\hline Range & $123-177$ & $5-13$ & $1 \cdot 7-5 \cdot 6$ & $0.2-4.3$ & $0.9-8.5$ & $0-9 \cdot 1$ \\
\hline $\begin{array}{l}\text { Cauda epididymidis } \\
\text { No. of animals }\end{array}$ & 18 & 16 & 4 & 8 & 6 & 17 \\
\hline Mean content & $\begin{array}{c}61 \cdot 8 \\
(29 \cdot 8)\end{array}$ & $\begin{array}{c}16 \cdot 9 \\
(26 \cdot 4)\end{array}$ & $\begin{array}{c}1 \cdot 13 \\
(2 \cdot 21)\end{array}$ & $\begin{array}{c}14 \cdot 65 \\
(14 \cdot 58)\end{array}$ & $\begin{array}{c}5 \cdot 2 \\
(3 \cdot 91)\end{array}$ & $\begin{array}{c}62 \cdot 5 \\
(62 \cdot 3)\end{array}$ \\
\hline $\mathrm{SD}$ & $\begin{array}{l}19 \cdot 9 \\
(5 \cdot 0)\end{array}$ & $\begin{array}{c}4 \cdot 7 \\
(2 \cdot 2)\end{array}$ & $\begin{array}{c}0 \cdot 11 \\
(1 \cdot 17)\end{array}$ & $\begin{array}{c}5 \cdot 53 \\
(6 \cdot 61)\end{array}$ & $\begin{array}{l}1 \cdot 10 \\
(1 \cdot 38)\end{array}$ & $\begin{array}{l}10 \cdot 5 \\
(6 \cdot 7)\end{array}$ \\
\hline Range & $33-112$ & $12-27$ & $0 \cdot 9-1 \cdot 6$ & $6 \cdot 6-23 \cdot 2$ & $3 \cdot 2-6 \cdot 6$ & $47 \cdot 3-79 \cdot 7$ \\
\hline$d f$ & $\frac{11 \cdot 18 * * *}{27}$ & 25 & $\begin{array}{l}2 \cdot 21 \\
8\end{array}$ & $\begin{array}{l}24 \cdot 39 * * * \\
13\end{array}$ & $\begin{array}{l}0 \cdot 49 \\
11\end{array}$ & $\begin{array}{l}15 \cdot 61 * * * \\
23\end{array}$ \\
\hline
\end{tabular}

Values in parentheses refer to data obtained by Crabo (1965) in adult bulls.

Statistical comparison (Student's $t$-test) between mean values obtained from analyses of fluid in the rete testis and cauda epididymidis of bull calves; $d f=$ degrees of freedom; the difference is considered to be 'almost significant' $(*)$ when probability $(P)$ is 0.01 to 0.05 ; 'significant' (**) when $P$ is 0.001 to 0.01 ; and 'highly significant' $(* * *)$ when $P$ is 0.001 or less.

TABLE 3

STATISTICAL COMPARISON (STUDENT'S $t$-TEST) BETWEEN THE MEAN VALUES RECORDED IN TABLE 2 FOR BULL CALVES AND THE MEAN VALUES REPORTED BY CRABO (1965) FOR THE ADULT BULLS

\begin{tabular}{|c|c|c|c|c|c|c|}
\hline & $\mathrm{Na}^{+}$ & $\kappa^{+}$ & $\mathrm{Ca}^{++}$ & $\mathrm{PO}_{4}^{---}$ & Protein & $G P C$ \\
\hline $\begin{array}{l}\text { Rete testis } \\
\quad t \\
\quad d f\end{array}$ & $\begin{array}{l}7 \cdot 02 * * * \\
18\end{array}$ & 18 & $13^{1.57}$ & $e^{2 \cdot 22 *}$ & $16^{1 \cdot 84}$ & $\begin{array}{l}0 \cdot 83 \\
14\end{array}$ \\
\hline $\begin{array}{l}\text { Cauda epididymidis } \\
t \\
d f\end{array}$ & $26^{4 \cdot 96 * * *}$ & $24^{5 \cdot 97 * * *}$ & $12^{1 \cdot 78}$ & $\begin{array}{l}0 \cdot 01 \\
18\end{array}$ & $13^{1 \cdot 78}$ & ${ }^{0.22}$ \\
\hline
\end{tabular}

epididymidis of bull calves. Table 3 gives a statistical comparison between epididymal plasma of bull calves and of adult bulls. In none of the samples collected did the volume of sperm fraction exceed $1 \%$ of the total volume of epididymal contents. 
As can be seen from the tables, the fluid taken from the rete testis of bull calves resembled in its composition both the blood plasma and the fluid in the rete testis of adult bulls. However, its sodium concentration was higher, and its potassium concentration was lower than in adult bulls. In both respects, the difference was shown to be highly significant. The concentration of inorganic phosphate was somewhat lower in the rete testis fluid of bull calves than in the analogous fluid of adult bulls, while the calcium, protein and glycerylphosphorylcholine concentrations were not significantly different. On the whole, the fluid in the rete testis of bull calves was more closely related to blood plasma than to the analogous fluid from adult bulls.

As can also been seen from the tables, the composition of epididymal plasma taken from the cauda epididymidis of bull calves (Table 2) differed markedly from that of the fluid taken from the rete testis, the only exceptions being calcium and protein. As in adult bulls, the epididymal plasma of the bull calves differed from the fluid in rete testis by having less sodium but more potassium, phosphate and glycerylphosphorylcholine; the protein content, however, was about the same. Since no analyses could be made of epididymal plasma from intermediate portions of the epididymis, it is difficult to say anything about the changes along the epididymal duct. Epididymal plasma of adult bulls differed from that of calves in the levels of both sodium and potassium (Table 3). In respect of both ions, the epididymal plasma of calves resembled the epididymal plasma in certain adult bulls with reduced sperm production (Gustafsson, 1966). The changed composition in the latter bulls was thought to be due to a lowered function of the caput epididymidis. It is difficult to say if the sodium and potassium levels of the epididymal plasma in the bull calves are due to the low sperm production or to the fact that the cauda epididymidis of bull calves is differentiated before the caput (Abdel-Raouf, 1960). The glycerylphosphorylcholine concentration in the epididymal plasma taken from the cauda epididymidis was about the same in the bull calves as in the adult bulls. Since, in the bovine, glycerylphosphorylcholine is mainly secreted in the cauda epididymidis (Gustafsson, 1966) this indicates that the cauda epididymidis of the bull calves matures early as regards its secretory function.

\section{REFERENCES}

ABdel-Raouf, M. (1960) The postnatal development of the reproductive organs in bulls with special reference to puberty. Acta endocr., Copenh. 34, Suppl. 49.

Bisнop, D. W. (1961) Biology of spermatozoa. In: Sex and Internal Secretions, 3rd edn, p. 707. Ed. W. C. Young. Williams \& Wilkins, Baltimore.

Crabo, B. (1965) Studies on the composition of epididymal content in bulls and boars. Acta vet. scand. 6, Suppl. 5.

Crabo, B. \& Gustafsson, B. (1964) Distribution of sodium and potassium and its relation to sperm concentration in the epididymal plasma of the bull. F. Reprod. Fert. 7, 337.

Gustafsson, B. (1966) Luminal contents of the bovine epididymis under conditions of reduced spermatogenesis, luminal blockage and certain sperm abnormalities. Acta vet. scand. Suppl. 17.

SNedecor, G. W. (1946) Statistical methods, 4th edn. Iowa State College Press, Ames, Iowa. 